\title{
CARIES RISK PROGNOSIS CRIIERIA IN CHILDREN WITH ENAMEL HYPOPLASIA OF THE PERMANENT TEETH, TAKING INTO ACCOUNI ANTHROPOGENIC ENVIRONMENTAL FACTORS
}

\section{Liubarets S.F., Antomonov M.Yu. КРИТЕРІЇ ПРОГНОЗУВАННЯ ВИНИКНЕННЯ КАРІЕСУ У ДТТЕЙ З ГППОПЛАЗІЕН ЕМАЛІ ПОСТІЙНИХ ЗУБІВ З УРАХУВАННЯМ АНТРОПОГЕННИХ ЧИННИКІВ ДОВКІЛЛЯ}

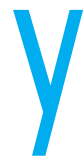

1ЛЮБАРЕЦЬ С.Ф., 2АНТОМОНОВ М.Ю. 1 Національний медичний університет ім. О.О. Богомольця, м. Київ 2ДУ «Інститут громадського здоров'я ім. О.М. Марзєєва НАМН України», м. Київ

УДК: $616.314002053 .202-$ 037:616.314.13 007.23:57.042

https://doi.org/10.32402/ dovkil2018.04.032

Ключові слова: діти, гіпоплазія, карієс, регресійний аналіз, іонізуюче випромінювання. спектрі стоматологічних хвороб чільне місце належить вадам твердих тканин зубів, зокрема системній гіпоплазії емалі (СГЕ) [1-3]. Основним ускладненням гіпоплазії є карієс зубів [4, 5]. Відомо, що СГЕ є наслідком впливу на організм різноманітних негативних чинників ендота екзогенного походження, у т.ч. антропогенні $[1,6]$.

Серед останніх, враховуючи наявність в Україні територій, контамінованих радіонуклідами внаслідок аварії на Чорнобильській AEC, актуальним $€$ вплив малих доз іонізуючого випромінювання (IB) на стан загального здоров'я та стоматологічний статус, зокрема дітей-мешканців цих регіонів $[6,7]$.
Дані літератури свідчать про можливість моделювання та прогнозування фізіологічних процесів і хвороб, у тому числі стоматологічних, зокрема каріозного ураження зубів [8-11] Математичні моделі щодо прогнозування розвитку ускладнень гіпоплазії емалі постійних зубів у дітей нині відсутні. Враховуючи все вищенаведене, застосування методів математичного прогнозування щодо розвитку каріозного ураження зубів як ускладнення вищевказаної вади твердих тканин зубів є актуальним.

Мета - підвищити ефективність прогнозування ймовірності виникнення карієсу як ускладнення у дітей з гіпоплазією емалі постійних зубів, які
КРИТЕРИИ ПРОГНОЗИРОВАНИЯ ВОЗНИКНОВЕНИЯ КАРИЕСА У ДЕТЕЙ С ГИПОПЛАЗИЕЙ ЭМАЛИ ПОСТОЯННЫХ ЗУБОВ С УЧЕТОМ АНТРОПОГЕННЫХ ФАКТОРОВ ОКРУЖАЮЩЕЙ СРЕДЫ

1 Любарец С.Ф., 2 Антомонов М.Ю.

${ }^{1}$ Национальный медицинский университет им. А.А. Богомольца, г. Киев, Украина

2ГУ «Институт общественного здоровья им. А.Н. Марзеева НАМН Украины», Г. Киев

В спектре стоматологических болезней ведущее место принадлежит порокам твердых тканей зубов, в частности гипоплазии эмали, основным осложнением которой является кариес зубов. Цель исследования - повысить эффективность прогнозирования вероятности возникновения кариеса как осложнения у детей с гипоплазией эмали постоянных зубов с учетом влияния негативных факторов окружающей среды на основе применения регрессионного анализа.

Материалы и методы. Объект исследования гипоплазия эмали и кариозное поражение постоянных зубов. Предмет исследования клинические и биохимические характеристики состояния твердых тканей зубов.

Результаты. Проведен анализ распространенности гипоплазии эмали постоянных зубов и ее осложнений у 2024 детей - жителей пяти регионов Украины с различным состоянием общего здоровья. Проанализирована распространенность кариеса зубов как осложнения системной гипоплазии эмали (СГЭ) в зависимости от возраста обследованных, состояния общего здоровья и влияния негативных факторов окружающей среды, в частности ионизирующего излучения. Для исследования влияния различных факторов на возникновение кариеса зубов как осложнения СГЭ был применен регрессионный анализ, модель была адекватной $(F=83,35, p<0,001)$. Наибольшее влияние на развитие кариеса зубов оказывает гигиеническое состояние полости рта (индекс GreenVermillion $=39,10 \%)$.

Выводы. На основе выделенных критериев, характеризующих гигиеническое состояние полости рта (индекс Green-Vermillion) и резистентность эмали зубов (тест эмалевой резистентности, содержание фосфатов в интактной эмали и ротовой жидкости), разработана регрессионная линейная модель для прогнозирования вероятности возникновения кариеса как осложнения у детей разных возрастных групп с гипоплазией эмали постоянных зубов. Предложенная регрессионная линейная модель может быть рекомендована для внедрения в практическую деятельность лечебных учреждений Украины, что позволит оптимизировать стоматологическое наблюдение за детскими контингентами различных возрастных групп, в том числе жителями территорий, контаминированных радионуклидами в результате аварии на Чернобыльской АЭС.

Ключевые слова: дети, гипоплазия, кариес, регрессионный анализ, ионизирующее излучение.

С Любарець С.Ф., Антомонов М.Ю.

СТАТТЯ, 2018. 
зазнали впливу негативних чинників довкілля, на основі застосування регресійного аналізу.

Матеріали і методи дослідження. Об'єкт дослідження гіпоплазія емалі та каріозне ураження постійних зубів Предмет дослідження - клінічні та біохімічні характеристики стану твердих тканин зубів.

До початку дослідження, згідно з умовами «Гельсинської Декларації» (2000), батьки дітей та діти більш старшого віку були поінформовані про мету та методи дослідження, про потенційні користь і ризики, можливий дискомфорт під час проведення діагностичних та інших маніпуляцій.

Методи дослідження передбачали

- обстеження ротової порожнини з урахуванням віку пацієнтів, показники гігієнічного стану порожнини рота (індекс Green Vermillion) та резистентності емалі зубів (визначення тесту емалевої резистентності (TEP), вмісту фосфатів (P) у ротовій рідині (РP), проведення кислотної біопсії інтактної емалі зубів (P);

- математичні методи: розрахунок первинних статистичних показників; для кількісних показників - оцінка виду емпіричних розподілів щодо відповідності нормальному (Гаусовому) розподілу, виявлення відмінностей між групами за статистичними ознаками; встановлення взаємозв'язку між змінними за допомогою параметричного та непараметричного кореляційного аналізів; метод багатомірної статистики (регресійний аналіз) [12].

Регресійна лінійна модель мала такий вигляд :

$y=a_{0}+a_{1} x_{1}+a_{2} x_{2}+\ldots a_{n} x_{n}$, де y - системна гіпоплазія емалі постійних зубів, ускладнена карієсом; $x_{1} \ldots, x_{n}$ - фактори, що впливають; $a_{0}, a_{1} \ldots, a_{n}-$ коефіцієнти моделі.

Для первинної підготовки таблиць та проміжних розрахунків використовувався пакет Excel. Основна частина математичної обробки виконувалася з використанням стандартного статистичного пакета Statistica 10.0 portable.

Результати досліджень та їх обговорення. Проведено аналіз поширеності гіпоплазії емалі постійних зубів та її ускладнень у 2024 дітей - мешканців п'яти регіонів України 3 різним станом загального здоров'я. Проаналізовано поширеність карієсу зубів як ускладнення СГЕ залежно від віку обстежених, стану загального здоров'я та впливу негативних чинників довкілля, зокрема IB. У дітей Північного регіону з 3-ю педіатричною групою здоров'я, які зазнали дії IB, цей показник був найвищим і становив порівняно з неопроміненими обстеженими віком 13-18 років $85,42 \%$ та $71,43 \%$ відповідно у дітей вікової групи 6-12 років $-44,00 \%$ та $23,61 \%$.

Відомо, що найбільш суттєво на розвиток карієсу зубів як ускладнення гіпоплазії емалі у дітей впливає гігієнічний стан порожнини рота. У групах дітей з СГЕ, особливо у мешканців територій, контамінованих радіонуклідами, показники гігієнічного індексу Green-Vermillion були найвищими $(1,5 \pm$ 0,66), що свідчить про задовільну гігієну порожнини рота. Це може бути обумовленим низкою факторів, у тому числі змінами структури емалі, які виникли до моменту прорізування зубів. Відомо, що при гіпоплазії порушення емалі визначається не тільки у ділянці видимих змін, а й по усій площі емалі, прилеглої до зони ураження. На межі переходу інтактної емалі у гіпоплазовану ділянку збільшується кількість пор різної величини і форми, що сприяє фіксації у них мікрофлори, яка може призводити до виникнення ускладнень, зокрема карієсу.

Стан резистентності емалі (визначався за показниками TEP та вмістом $P$ в інтактній емалі і PP) у дітей з гіпоплазією також прямо або опосередковано впливав на появу каріозного ураження зубів. Показники ТЕР в обстежених дітей з гіпоплазією емалі відповідали середньому ступеню резистентності і свідчили про середню стійкість щодо розвитку карієсу зубів. Вміст Р у РР був найменшим в обстежених 3 СГЕ та 2-ю групою здоров'я і у групі осіб з СГЕ та 3-ю групою здоров'я, які зазнають дії IB $(3,04 \pm 0,20)$ ммоль/л і $(3,26 \pm$ 0,92) ммоль/л відповідно). Аналогічні зміни простежувались і щодо вмісту фосфатів в інтактній емалі постійних зубів у дітей вищевказаних груп $(0,52 \pm 0,40)$ ммоль/л і $(0,54 \pm$ 0,34) ммоль/л відповідно). Отримані нами дані відповідають клінічним даним ряду інших авторів [13].

Результати оцінки показників стоматологічного статусу та вищезазначених складових мінерального обміну в обстежених нами мешканців різних регіонів України дозволили застосувати математичний метод - регресійний аналіз для прогнозування ймовірності виникнення карієсу як ускладнення гіпоплазії емалі постійних зубів у дітей різних вікових груп. Розроблена нами лінійна математична модель містила показники, які виявилися найбільш значущими при проведенні комплексного обстеження дитячих контингентів (табл.).

Було визначено параметри моделі, яка була адекватною $(F=83,35, p<0,001)$. За допомогою Бета-коефіцієнта були розраховані частки вкладів факторних перемінних (табл.).

Параметри лінійної математичної моделі щодо розвитку ускладнень у дітей Таблиця з гіпоплазією емалі постійних зубів

\begin{tabular}{|l|c|c|c|c|c|c|}
\hline \multicolumn{1}{|c|}{$\begin{array}{c}\text { Фактори, що впливають } \\
\left(\mathrm{x}_{1} \ldots, \mathrm{x}_{\mathrm{n}}\right)\end{array}$} & $\begin{array}{c}\text { Бета } \\
(\beta)\end{array}$ & $\begin{array}{c}\text { Похибка } \\
\mathrm{S}_{\beta}\end{array}$ & $\begin{array}{c}\text { Коефіцієнти } \\
\text { моделі }\left(\mathrm{a}_{0} \ldots, \mathrm{a}_{\mathrm{n}}\right)\end{array}$ & $\begin{array}{c}\text { Похибка } \\
\mathrm{S}_{\mathrm{a}}\end{array}$ & $\begin{array}{c}\text { Коефіцієнт } \\
\mathrm{t}\end{array}$ & $\mathrm{p}$ \\
\hline Вільний член & & & $0,757\left(\mathrm{a}_{0}\right)$ & & & \\
\hline Вік $\left(\mathrm{x}_{1}\right)$ & $-0,196$ & 0,022 & $-0,051\left(\mathrm{a}_{1}\right)$ & 0,006 & $-8,954$ & $<0,001$ \\
\hline Індекс Green-Vermillion $\left(\mathrm{x}_{2}\right)$ & 0,224 & 0,02 & $0,288\left(\mathrm{a}_{2}\right)$ & 0,026 & 10,968 & $<0,001$ \\
\hline ТЕР $\left(\mathrm{x}_{3}\right)$ & 0,178 & 0,022 & $0,13\left(\mathrm{a}_{3}\right)$ & 0,016 & 8,05 & $<0,001$ \\
\hline Інтактна емаль (P) $\left(\mathrm{x}_{4}\right)$ & $-0,064$ & 0,021 & $-0,162\left(\mathrm{a}_{4}\right)$ & 0,054 & $-3,017$ & $=0,003$ \\
\hline Ротова рідина $(\mathrm{P})\left(\mathrm{x}_{5}\right)$ & $-0,063$ & 0,021 & $-0,071\left(\mathrm{a}_{5}\right)$ & 0,023 & $-3,077$ & $=0,002$ \\
\hline
\end{tabular}


Найбільший вклад щодо розвитку карієсу зубів як ускладнення гіпоплазії емалі у дітей належить гігієнічному стану порожнини рота (індекс GreenVermillion $=39,10 \%$ ), найменший - показнику вмісту фосфатів у $\mathrm{PP}(3,09 \%)$.

Прогностична модель з урахуванням отриманих нами значень факторів, що впливають, представлена формулою:

$y=0,757-0,051\left(x_{1}\right)+0,288\left(x_{2}\right)$ $+0,13\left(x_{3}\right)-0,162\left(x_{4}\right)-0,071$ $\left(x_{5}\right)$,

де у - ускладнення СГЕ; $x_{1}$ - вік; $x_{2}$ - індекс Green-Vermillion; $x_{3}-$ TEP; $x_{4}$ - вміст Р в інтактній емалі; $\mathrm{X}_{5}$ - вміст Р у ротовій рідині.

у літературі $€$ поодинокі роботи у галузі стоматології щодо прогнозування виникнення ускладнень, зокрема карієсу зубів, у дитячих контингентів. На основі вивчення причинно-наслідкових зв'язків впливу чинників довкілля на стоматологічний статус дітей 3 використанням множинного кореляційно-регресійного аналізу [14] було запропоновано математичну модель залежності між показником інтенсивності карієсу постійних зубів та накопиченням в емалі хімічних елементів, зокрема фосфатів.

Ця модель підтвердила, що у неоднакових за геохімічною ситуацією регіонах вміст різних хімічних елементів впливає на резистентність емалі і сприяє виникненню карієсу. Іншими дослідниками було створено регресійну модель для прогнозування захворювань тканин пародонту - залежності ступеня запалення ясен від рівня імуноглобуліну A [9].

Однак зазначені вище моделі базувалися на використанні лише поодиноких показників окремих ланок стоматологічного статусу дітей. Дані щодо прогнозування розвитку карієсу як ускладнення гіпоплазії емалі постійних зубів у дітей у літературі відсутні. Запропонована нами модель дозволяє прогнозувати розвиток карієсу у дітей з СГЕ і базується на комплексному підході до проблеми, оскільки враховує вік обстежених, показники гігієнічного стану порожнини рота (індекс Green-Vermillion) та резистентності емалі зубів (ТЕР, вміст фосфатів у ротовій рідині та емалі зубів).

\section{Висновки}

1. На основі виділених критеріїв, що характеризують гігієнічний стан порожнини рота (індекс Green-Vermillion) та резистентність емалі зубів (тест емалевої резистентності, вміст фосфатів в інтактній емалі та ротовій рідині), розроблено регресійну лінійну модель для прогнозування ймовірності виникнення карієсу як ускладнення у дітей різних вікових груп з гіпоплазією емалі постійних зубів.

2. Запропонована регресійна лінійна модель може бути рекомендована для впровадження у практичну діяльність лікувальних закладів України, що дозволить оптимізувати стоматологічний нагляд щодо дитячих контингентів різних вікових груп, у томі числі мешканців територій, контамінованих радіонуклідами внаслідок аварії на Чорнобильській АЕС.

Перспективи подальших досліджень. Впровадження регресійної лінійної моделі для прогнозування ймовірності виникнення карієсу як ускладнення гіпоплазії емалі постійних зубів у практичну діяльність лікувальних закладів України дозволить оптимізувати стоматологічний нагляд щодо дитячих контингентів різних вікових груп, у томі числі мешканців територій, контамінованих радіонуклідами внаслідок аварії на Чорнобильській АEC.

Робота є фрагментом виконання науково-дослідної роботи кафедри дитячої терапевтичної стоматології та профілактики стоматологічних захворювань Національного медичного університету імені О.О. Богомольця «Загальні чин ники у формуванні стоматологічного здоров'я дітей та підлітків» (№ державної реєстрації 0113U001484).

\section{ЛІТЕРАТУРА}

1. Білоус І.В. Чинники ризику розвитку та шляхи профілактики системної гіпоплазії емалі зубів у дітей : автореф. дис. ... канд. мед. наук. Ів.-Франківськ, 2004. 21 с.

2. Бєліков О.Б., Бучок Р.А. Поширеність некаріозних уражень твердих тканин зубів серед студентів і молоді та причинно-наслідкові зв'язки їх виникнення. Буковинський медичний вісник. 2012. Т. 16. № 4 (64). C. 26-30.

3. Liubarets S. Dental status of children with the teeth formation disorders. Eureka: Health Sciences. 2016. № 2. P. 18-24. 4. Задорожна І.В., Поворознюк В.В. Поширеність та інтенсивність карієсу зубів у дітей України: результати клініко-епідеміологічного обстеження // Журнал «Боль. Суставы. Позвоночник». 2014. № 1-2 (1314). C. $26-29$

5. Hong L., Levy S.M., Warren J.J., Broffitt B. Association between enamel hypoplasia and dental caries in primary second molars : A Cohort Study. Caries Res. 2009. № 43 (5). P. 345-353.

6. Лабій Ю.А. Шляхи підвищення резистентності емалі зубів у дітей, хворих на системну гіпоплазію емалі, що проживають у районах з різним антропогенним забрудненням автореф. дис. .... канд. мед. наук. Ів.-Франківськ, 2016. 15 с.

7. Любарець С.Ф. Розповсюдженість вад твердих тканин зубів у дітей, які мають статус постраждалих від наслідків аварії на чAEC. Сучасні аспекти військової стоматології : зб. наук. праць. К., 2013. Вип. 2. С. 100-103.

8. Даценко Г.В. Моделювання методом покрокового регресійного аналізу індивідуальних показників реоенцефалограми у здорових юнаків та дівчат Поділля мезоморфного соматотипу залежно від антропосоматотипологічних параметрів тіла. Вісник проблем біології $і$ медицини. 2011. Вип. 3, Т. 2 (88). С. 55-58.

9. Кривенко Л.С. Прогнозування ступеня запалення ясен у дітей з бронхіальною астмою методом регресійного аналізу. Інноваційні технології у стоматології : матер. наук.-практ. конф., 23.09.2016. Тернопіль : ТДМУ, 2016. С. 72-73.

10. Марченко А.В., Петрушанко Т.О., Гунас І.В. Моделювання за допомогою регресійного аналізу трансверзальних розмірів верхньої й нижньої щелепи та сагітальних характеристик зубної дуги в юнаків залежно від особливостей одонтометричних і кефалометричних показників. Вісник морфології. 2017. T. 23. № 1. C. 107-111.

11. Орловський В.О., Шинкарук-Диковицька М.М., Гунас І.В. Моделювання за допомогою регресійного аналізу індивідуальних лінійних розмірів малих кутніх зубів залежно від кефалометричних показників практично здорових чоловіків із різних регіонів України. Вісник наукових досліджень. 2018. № 1. С. 93-95. 
CARIES RISK PROGNOSIS CRITERIA IN CHILDREN WITH ENAMEL HYPOPLASIA OF THE PERMANENT TEETH, TAKING INTO ACCOUNT ANTHROPOGENIC ENVIRONMENTAL FACTORS

1 Liubarets S. F., 2 Antomonov M.Yu.

${ }^{1}$ National O.O. Bohomolets Medical University, Kyiv, Ukraine

2State Institution «O.M. Marzieiev Institute for Public Health, NAMSU»,

Kyiv, Ukraine

The hard dental tissue lesions, enamel hypoplasia in particular, represent a significant problem within the broad range of dental pathologies. Dental caries is the most common hypoplasia complication.

Objective: On the basis of regression analysis, we increased the efficiency of the prognosis of caries beginning as a complication in the children with permanent teeth enamel hypoplasia, taking into account the influence of negative environmental factors.

Materials and methods: The study object is an enamel hypoplasia and carious lesions of permanent teeth. The study subject is the clinical and biochemical characteristics of hard dental tissues. Results: Analysis of the prevalence of enamel hypoplasia of permanent teeth and its complications in 2024 children - residents of five regions of Ukraine, referred to various health groups were analyzed. The prevalence of dental caries as a complication of systematic enamel hypoplasia (SEH) was analyzed depending on the respondents' age, health group and harmful environmental factors, ionizing radiation in particular. In order to study the influence of various factors on the dental caries as a complication of SEH, a regression analysis was applied, the model was adequate $(F=83.35, p<0.001)$. Hygienic state of oral cavity makes the most important contribution to the development of dental caries (Green-Vermillion index $=39.10 \%$ ).

Conclusions: Based on the selected criteria of hygienic oral pattern (Green-Vermillion index) and teeth enamel resistance (enamel resistance test, phosphate content in intact enamel and oral fluid), a regression linear model was created to predict the probability of caries as a complication in children of different age groups with permanent teeth enamel hypoplasia.

The proposed regression linear model can be recommended for the implementation into practice of medical institutions of Ukraine to optimize the dental monitoring in the children of different age groups, including the inhabitants of the territories contaminated with radionuclides after Chornobyl accident.

Keywords: children, hypoplasia, caries, regression analysis, ionizing radiation.
12. Антомонов М.Ю. Математическая обработка и анализ медико-биол. данных. 2-е изд. К. : Мединформ, 2018. 579 с.

13. Боровский Е.В, Леонтьев В.К. Биология полости рта. Москва : Медицинская книга ; Н. Новгород : Изд-во НГМА, 2001. 304 с

14. Остапко О.І. Наукове обґрунтування шляхів та методів профілактики основних стоматологічних захворювань у дітей у регіонах з різним рівнем забруднення довкілля : автореф. дис. ... докт. мед. наук. К., 2011. 41 с. REFERENCES

1. Bilous I.V. Chynnyky ryzyku rozvytku ta shliakhy profilaktyky systemnoi hipoplazii emali zubiv u ditei : avtoref. dys. ... kand. med. nauk [Risk Factors of the Development and the Ways of the Prevention of Systematic Hypoplasia of Teeth Enamel in the Children : Abs. Cand. Med. Sci. Diss.]. Ivano-Frankivsk; 2004 : 21 p. (in Ukrainian).

2. Bielikov O.B. and Buchok R.A Bukovynskyi medychnyi visnyk. 2012 ; 4 (64) : 26-30 (in Ukrainian). 3. Liubarets S. Dental Status of Children with the Teeth Formation Disorders. Eureka: Health

Sciences. 2016 ; 2 : 18-24

4. Zadorozhna I.V. and

Povorozniuk V.V. Bol. Sustavy.

Pozvonochnik. 2014 ; 1-2 (13-14)

: 26-29 (in Ukrainian).

5. Hong L., Levy S.M.

Warren J.J. and Broffitt B. Caries

Res. 2009 ; 43 (5) : 345-353.
6. Labii Yu.A. Shliakhy pidvyshchennia rezystentnosti emali zubiv u ditei, khvorykh na systemnu hipoplaziiu emali, shcho prozhyvaiut $\mathrm{v}$ raionakh iz riznym antropohennym zabrudnenniam avtoref. dys. ... kand. med. nauk [The Ways of the Increase of Teeth Enamel Resistance in the Children with a Systematic Enamel Hypoplasia Residing in the Regions with Different Anthropogenic Contamination : Abs. Cand. Med. Sci. Diss.]. Ivano-Frankivsk ; 2016 : 15 p. (in Ukrainian)

7. Liubarets S.F. Rozpovsiudzhenist vad tverdykh tkanyn zubiv u ditei, yaki maiut status postrazhdalykh vid naslidkiv avarii na ChAES [Prevalence of the Hard Teeth Tissue Defects in the Children Suffered from the Consequences of the Accident at the ChNPP]. In : Suchasni aspekty viiskovoi stomatolohii: zbirnyk naukovykh prats [Modern Aspects of Military Stomatology: Collection of Scientific Works]. Kyiv ; 2013 ; Iss. II : 100-103 (in Ukrainian).

8. Datsenko H.V. Visnyk problem biolohii i medytsyny. 2011 ; Iss. 3; Vol. 2 (88) : 55-58 (in Ukrainian).

9. Kryvenko L.S.

Prohnozuvannia stupeniu zapalennia yasen $u$ ditei $z$ bronkhialnoiu astmoiu metodom rehresiinoho analizu [The Prognosis of the Gingiva Inflammation in the Children with Bronchial Asthma by the Method Regression Analysis].
In : Innovatsiini tekhnolohii v stomatolohii : materialy nauk.-prakt. konf. [Innovative Technologies in Stomatology : Mater. Sci.-Pract. Conf.]. Ternopil ; 2016 : 72-73 (in Ukrainian).

10. Marchenko A.V., Petrushanko T.O. and Hunas I.V. Visnyk morfolohii. 2017 ; 23 (1) : 107111 (in Ukrainian).

11. Orlovskyi V.O., ShinkarukDykovytska M.M. and Hunas I.V. Visnyk naukovykh doslidzhen. 2018 ; 1 : 93-95 (in Ukrainian).

12. Antomonov M.Yu. Matematicheskaya obrabotka i analiz mediko-biologicheskikh dannykh. 2-e izd. [Mathematical Processing and Analysis of Medico-Biological Data]. Kyiv : Medinform ; 2018 : 579 p. (in Ukrainian).

13. Borovskiy E. and Leont'ev V. Biologiya polosti rta [Biology of Oral Cavity]. Moscow : Meditsinskaya kniga ; Nizhniy Novgorod : izd-vo NGMA ; 2001 : 304 (in Russian)

14. Ostapko O.I. Naukove obhruntuvannia shliakhiv ta metodiv profilaktyky osnovnykh stomatolohichnykh zakhvoriuvan u ditei v rehionakh z riznym rivnem zabrudnennia dovkillia : avtoref. dys. ... dokt. med. nauk [Scientific Substantiation of the Ways and the Methods for the Prevention of the Main Stomatologic Diseases in the Children in the Regions with Different Environmental Contamination : Abstract of Dr. Med. Diss.]. Kyiv ; 2011 : 41 p. (in Ukrainian). Надійшла до редакції 017.08.2018 